\title{
POMEN TERCIARNIH DEJAVNOSTI V RAZVOJU LJUBLJANE
}

\author{
Angelca Rus \\ Mestna občina Ljubljana, Oddelek za urbanizem, Poljanska 28, SI-I000 Ljubljana \\ e-mail: angelca.rus@ljubljana.si
}

Pregledni znanstveni članek

COBISS 1.02

\section{Izvleček}

V zadnjih treh desetletjih smo priča prestrukturiranja gospodarstva. Terciarni sektor dejavnosti je v porastu. Vedno težja je razmejitev med sekundarnim in terciarnim sektorjem. V prispevku so prikazani novejši trendi opredeljevanja in razvoja storitvenih dejavnosti v svetu in Sloveniji. Posebej je izpostavljen razvoj storitev v Ljubljani, struktura zaposlenih v terciarnem sektorju ter obstoječi trendi lokacije teh dejavnosti.

Ključne besede: storitvene dejavnosti, terciarne dejavnosti, razvoj dejavnosti, struktura zaposlenih, Ljubljana, Evropa.

\section{THE SIGNIFICANCE OF THE SERVICE SECTOR FOR THE DEVELOPMENT OF LJUBLJANA}

\begin{abstract}
During the last three decades we have been witnessing economic changes. The service sector has been growing. However it is increasingly more difficult to distinguish between the secondary and services sectors. The article deals with recent global and local Slovene trends in definition and development of the service sector. Special emphasis is given to the development of services in Ljubljana, the structure of employment and ongoing trends in location of these activities.
\end{abstract}

Key words: Services, tertiary activities, employment structure, Ljubljana, Europe. 


\section{UVOD}

$\mathrm{V}$ zadnjih treh desetletjih je $\mathrm{v}$ vseh večjih urbanih evropskih središčih, tako tudi $\mathrm{V}$ Sloveniji, prišlo do zasuka $\mathrm{v}$ prestrukturiranju gospodarstva od materialnih predelovalnih dejavnosti (sekundarni sektor) v nematerialne - storitvene dejavnosti. Priča smo močnemu prestrukturiranju delovnih mest, pri čemer tradicionalne industrijske panoge nadomeščajo druge dejavnosti. Te spremembe ne povzročajo samo povečane konkurence $\mathrm{v}$ celotnem urbanem sistemu, ampak tudi konkurenco znotraj samih mest oziroma med mestnim središčem in obrobjem. Cenejša in predvsem dostopnejša ponudba zemljišč na obrobju mest $\mathrm{z}$ dobro dostopnostjo in zagotavljanjem zadostnega števila parkirnih mest so sprožili proces odseljevanja storitev na obrobje, tudi tistih, za katere smo včasih menili, da so ključnega pomena za funkcioniranje in rast mestnega središča (npr. finance in zavarovalnice).

V svojem prispevku bomo skušali opredeliti pojem terciarnih dejavnosti ter problematiko razmejevanja med sekundarnim in terciarnim sektorjem. Posebej bomo opozorili na nove trende storitvenih dejavnosti in pričakovane spremembe ter vidike tekmovalnosti na področju lokacije storitev. Proces prestrukturiranja dejavnosti in zaposlenih bomo osvetlili na vzorčnem primeru Mestne občine Ljubljane.

\section{OPREDELITEV POJMA TERCIARNE (STORITVENE) DEJAVNOSTI}

Po tradicionalni definiciji se terciarni (storitveni) sektor razlikuje od primarnega in sekundarnega sektorja predvsem po tem, da ne postavlja v ospredje proizvodnje materialnih dobrin, ampak nudi nematerialne storitve.

Temelje sektorjev dejavnosti sta postavila ekonomista A.G.B. Fischer in C. Clark (1940), ki sta v 30. letih 20. stoletja začela s proučevanjem storitvenih dejavnosti in že takrat predlagala klasifikacijsko teorijo treh sektorjev dejavnosti. Bistvo te delitve je naslednje:

\begin{tabular}{|l|l|l|}
\hline I. sektor & Kmetijstvo, ribištvo, lov. & Delovna sila je prosto razporejena. \\
\hline II. sektor & Anorganska predelava - industrija. & Najprej naraščanje, nato upadanje delovne sile. \\
\hline III. sektor & $\begin{array}{l}\text { Ostale gospodarske panoge: trgovina, } \\
\text { obrt, transport, banke, zavarovanja, uprava } \\
\text { in drugo. }\end{array}$ & Porast delovne sile. \\
\hline
\end{tabular}

Iz dosedanjih geografskih raziskav je najbolj poznana in tudi najbolj uporabljena teorija, ki jo je razvil Fourastie (1954). On razlikuje sektorje glede na tehnološki napredek posameznega sektorja. Po njem naj bi bil primarni sektor srednje velik, če je pri tem sekundarni sektor največji. Terciarnemu sektorju sicer napoveduje porast, ki pa ni nujno povezan direktno s tehnološkim napredkom, saj naj bi bil razvoj tega sektorja bolj odvisen od povečanega povpraševanja gospodinjstev po določenih storitvah. Razvoj je pokazal, da se je od takrat ta sektor povečeval tudi na račun podjetniških storitev, obenem pa je postajal vse bolj odvisen od tehnološkega razvoja (razvoj računalniške tehnologije). 
Nezadržen razvoj visoko vrednotenih storitev je pripeljal do vprašanja, kaj je pravzaprav »kvartarni sektor« dejavnosti, saj je terciarni sektor s svojo funkcijo, ki zahteva vse višjo izobrazbo in odgovornost praktično, zabrisal prvotni pomen dejavnosti v kvartarnem sektorju. Odpira pa se nov sektor, ki ga je A. Neuhoff (1998) poimenoval »kvintarni sektor« ravno iz vidika krepitve znanstvenega inženiringa.

Kvintarni sektor?

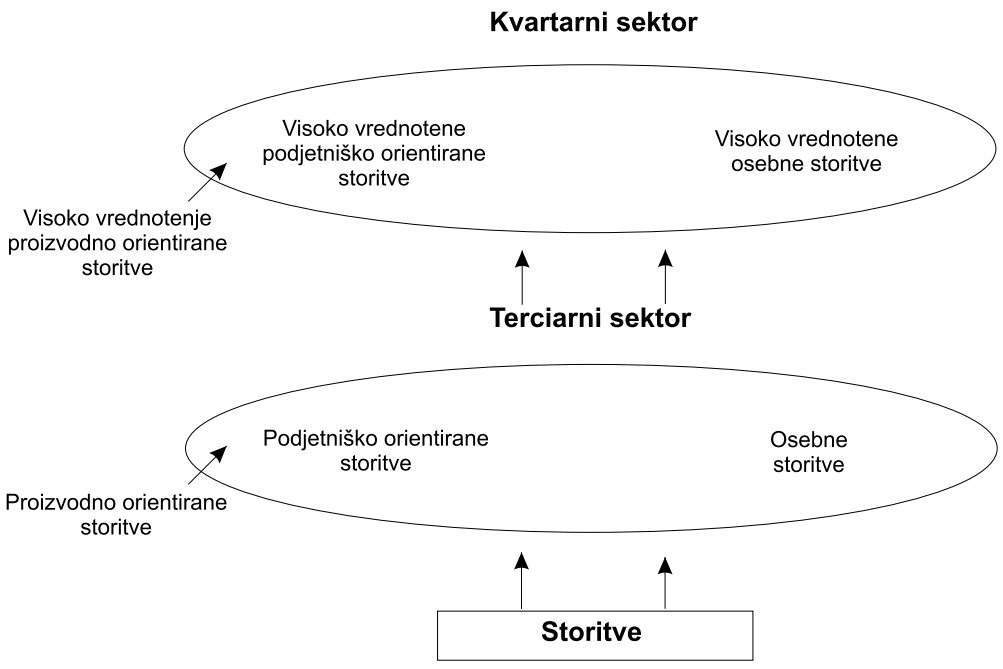

Vir: Sistematika uporabljenih storitvenih kategorij (A. Neuhoff)

Source: The systemisation of applied services categories. (A. Neuhoff)

Najbolj pogoste definicije, zlasti v statistiki, opredelijo kot storitvene dejavnosti tiste dejavnosti, ki niso produktivne, oziroma obsegajo ekonomske proizvode, ki niso stvarna dobrina. Proces izdelave storitve je možno razdeliti v dve fazi:

- $\quad$ priprava storitve (na podlagi potencialne proizvodnje, npr. izdelava avtomobila). V tej fazi je storitev še zelo materializirana (npr. postavitev strojev, infrastrukture), prihaja do prvih stikov med ponudnikom in povpraševalcem.

- $\quad$ priprava končne kombinacije (sinhroni kontakt) z zunanjim faktorjem (npr. avto v delavnici je zunanji faktor). V tej fazi je vključenih že več storitev, ki so nujno potrebne (npr. programska oprema, rutina pristopa za prodajo itd.).

Poleg enostavnih ločevanj storitev je prišlo do velikih sprememb na področju »visoko vrednotenih storitev«, ki imajo več možnih pojmovnih razlag. Heterogenost teh storitvenih področij posega na pojme kot so: proizvodne storitve, informacijski sektor, kvartarni sektor, 
intelektualne storitve, poslovne storitve itd. Mišljene so vse dejavnosti, ki zahtevajo višjo izobrazbeno strukturo in bistveni prispevek pri procesu odločanja podjetij.

Na kratko bi lahko visoko vrednotene storitve razumeli kot dejavnosti, ki zahtevajo višjo izobrazbo in ni nujno, da so povezane pretežno z materialno blagovno produkcijo. Vendarle pa izpeljejo kompleten proces izvedbe posla tudi s pomočjo drugih storitev. To so zlasti funkcije s področja davčnih, gospodarskih, tehnoloških in pravnih obdelav, financ, organizacijskega in proizvodnega upravljanja, zavarovanj, osebnega izobraževanja, kakor tudi na področju raziskav trga in mnenj, oglaševanj itd.

$\mathrm{V}$ tesni povezanosti s problemom definicije pojma storitvene dejavnosti je definicija terciarnega oziroma kvartarnega sektorja. $\mathrm{Z}$ razvojem in prestrukturiranjem dejavnosti, visokim tehnološkim razvojem, se je pokazalo, da je klasično razmejevanje med sekundarnim in terciarnim sektorjem dejavnosti izgubilo na pomenu, ker:

1. imajo mnoge dobrine »hibriden« značaj (stvarne dobrine/nosilci informacij/storitev). Kaj je pravzaprav CD? Je stvarna dobrina? V mnogih blagovnih izdelkih se povečuje delež nematerialnih vrednostnih stvaritev (informacije, programska oprema, servis);

2. mnoga podjetja proizvajajo tako stvarne kot nematerialne dobrine. Vedno manj je klasičnih dobrin (trgovine, osebnih storitev), vedno bolj se povečuje vloga informacij in znanja. Informacije in znanje so dobrine, pa tudi proizvodni in lokacijski faktor (etrgovina, e-uprava).

\section{TREND RAZVOJA STORITVENIH/TERCIARNIH DEJAVNOSTI}

Pred več kot 50 leti je Jean Fourastie razvil teorijo, da se bo terciarni sektor znatno povečeval in da bomo vstopili v obdobje »terciarne« oziroma »storitvene« družbe, kar se že uresničuje. Uresničila se je tudi napoved, da bodo glavni delež trženja predstavljale nematerialne dobrine in storitve, da bo poklicna struktura slonela na visoko kvalificirani dejavnosti. Vendar je terciarizacija dejavnosti prinesla tudi visok delež brezposelnosti, saj je ostalo zelo malo storitev, ki bi vključevale nekvalificirano oziroma nizko kvalificirano delovno silo (npr. področje čiščenja, posameznih trgovin, pomožna delovna sila).

V vseh razvitih državah se kaže trend sektorskih strukturnih sprememb: delež primarnega sektorja je padel pod $10 \%$, podobno se dogaja s sekundarnim sektorjem, ki je že padel pod 30 \%, medtem ko terciarni sektor še vedno narašča. V osnovi je terciarni sektor težko definirati, saj nekateri vidijo, da se delo v tem sektorju (npr. informacijski proizvodi kot CD, filmi) izdeluje kot blagovni proizvod, drugi pa trdijo, da so v tem sektorju le nematerialni proizvodi oziroma storitve (npr. frizer).

Terciarni sektor vključuje večji delež družbenega dela. V okvir blagovne produkcije se posredno vključujejo ostale dejavnosti, kot so: znanost, transport, komunikacija, energetska oskrba, izobrazba, področje zdravja in državnih socialnih služb in storitev. To neproduktivno delo (po klasični definiciji) sicer še ni zadostno ovrednoteno, postaja pa vedno večje. V terciarnem sektorju srečamo tudi takšna dela, ki imajo opravka z ustvarjanjem informacijskih izdelkov: CD, programska oprema, filmi, video itd. 
Razvojni trendi terciarnih dejavnosti se odražajo zlasti na naslednjih področjih:

- Drastično upadanje delovnih mest $\mathrm{v}$ tradicionalni industrijski panogi zaradi istočasnega nastajanja novih gospodarskih storitev in posledično nove informacijske in komunikacijske tehnologije. To pomeni, da se bo sčasoma spremenil položaj in struktura zaposlenih, povečale se bodo potrebe po nadaljnjem izobraževanju in potrebni prekvalifikaciji.

- $\quad$ Preusmeritve na nove strukturne in proizvodne procese. Tega se bodo morali zavedati tako firme kot podjetja. Potrebnih bo vedno več timsko orientiranih delovnih procesov ter vedno več kvalificiranih in motiviranih delavcev, ki bodo lahko izpolnili pričakovanja delodajalcev.

- $\quad$ Spreminjajo se časovne oblike razporeditve dela in delovni odnosi.

Terciarizacija pogojuje $\mathrm{v}$ zadnjih tridesetih letih pomemben trend urbanemu in ekonomskemu razvoju. V ZDA je bil ta proces opazen že med obema svetovnima vojnama, danes znaša ta delež že 80 \%. Evropske metropole so s svojimi 74 \% še vedno v fazi prestrukturiranja. Največji delež beležijo mesta Beneluxa (90\%), ostale metropole komaj 60 \%.

Za razvoj terciarnih dejavnosti ni dovolj, da se ta dejavnost razvija razpršeno, ampak zahteva specializacijo in povezovanje podobnih panog (npr. finančnih storitev), kar pomeni, da gre tudi za koncentracijo strokovnjakov. Prav tako ni nujno da ima koncentracija določenih storitev samo lokalni pomen, saj je povpraševanje in izmenjava informacij mnogo širša. Sem sodijo npr. finančne in zavarovalniške storitve, ki so tudi izrazito marketinško usmerjene.

Nov razvojni impulz pomeni specializacija storitvenih dejavnosti, ki lahko prevzame konkurenco na nacionalni ali tudi mednarodni ravni. Hierarhijo na področju finančnih storitev dominira Luxemburg z več kot 200 mednarodnimi bankami, sledijo Frankfurt, Zuerich. Po podjetniških storitvah npr na drugi strani prednjačijo Milano, Torino in Lyon. To so mesta, kjer je bila močna industrija, iz katere so se razvila storitvena podjetja in se locirala tudi v manjših centrih. Aglomeracija s specializacijo v trgovini in gostinstvu se je skoncentrirala predvsem okoli alpskega prostora. Tu igrajo posebno vlogo zlasti pokrajinske atraktivnosti in turistične (npr. Monaco) ali oskrbne funkcije (npr. Insbruck). Na področju trgovske dejavnosti se trgovine internacionalizirajo in povezujejo v vedno večje poslovne verige.

\section{TEKMOVALNOST NA PODROČJU LOKACIJE STORITVENIH DEJAVNOSTI}

Tekmovalnost lokacije storitvenih dejavnosti ne vlada samo znotraj evropskega sistema mest, ampak tudi znotraj samih aglomeracij. Dokaz te tekmovalnosti so lokacijske pogojenosti storitev, ki znotraj poslovnih mestnih središč niso mogle več zadovoljevati njihovih potreb. Selitev teh dejavnosti iz centra na mestni rob pravzaprav ni novo. Ta proces se začne že v 70-ih letih, ko se selijo površinsko intenzivni trgovski centri na mestni rob (npr. trgovine z gradbenim materialom, vrtnarski centri, supermarketi itd). Ponudba prostih površin v okolici ni omogočala samo nastajanje novih trgovin, ampak je zagotavljala tudi dovolj parkirnih mest. Torej trgovinska dejavnost je stopila že zelo zgodaj v konkurenco s svojim centrom. 
Počasi je zajela suburbanizacija tudi panoge, ki so doslej veljale za tipične centralno mestne. Najprej so se preselile tiste vzporedne storitvene dejavnosti, ki so bile neposredno povezane s poslovanjem trgovskih centrov (banke, zavarovalnice, razni biroji itd). Zlasti presenetljiva je bila tudi selitev bank, ki niso imele nobenih direktnih stikov s strankami. Eden od pomembnih vzrokov so bile tudi visoke najemnine poslovnih prostorov v mestnih središčih.

Koncentracija dejavnosti na obrobju je prinesla nove probleme. Spremenili so se prometni tokovi zaradi migracij. Poleg tradicionalnih migracijskih tokov, ki so usmerjeni predvsem iz periferije v center, se začne koncentracija prometa tudi v perifernih območjih.

\section{RAZVOJ TERCIARNEGA SEKTORJA V LJUBLJANI}

Za analiziranje razvoja terciarnega sektorja $\mathrm{v}$ Ljubljani smo uporabili uradne podatke Statističnega urada Republike Slovenije in njihovo klasifikacijo dejavnosti. Z vstopom Slovenije v Evropsko unijo je na statističnem področju prevzela tudi mednarodne klasifikatorje dejavnosti. S tem sta ukinjena Enotna klasifikacija dejavnosti, ki je zajemala 14 osnovnih dejavnosti, in Odlok o določitvi gospodarskih in negospodarskih dejavnosti. Stare šifrante je nadomestila »Standardna klasifikacija dejavnosti (SKD), ki je obvezen nacionalni standard, kateri se uporablja pri evidentiranju, zbiranju, obdelovanju, analiziranju, posredovanju in izkazovanju podatkov, povezanih z dejavnostjo. SKD se uporablja za določanje glavne dejavnosti in za razvrščanje poslovnih subjektov in njihovih delov za potrebe uradnih in drugih administrativnih zbirk podatkov (registri, evidence, podatkovne baze ipd) ter za potrebe statistike in analitike $\mathrm{v}$ državnem in mednarodnem merilu na različnih ravneh primerjanja in odločanja. Standardna klasifikacija dejavnosti (SKD) iz 1. 2002 se vsebinsko in strukturno skoraj povsem ujema z NACE (Nomenclature Generale des Activites Economiques dans les Communautes Europeenes) - Rev. 1.1 klasifikacijo dejavnosti, ki je obvezna v Evropski uniji, razen v šifri za delitev razredov v nacionalne razrede. SKD je hierarhično razčlenjena na 17 področij dejavnosti, ki so označene s črkami od A do Q« (Statistični urad R Slovenije).

$\mathrm{V}$ strokovni literaturi se storitvene dejavnosti največkrat delijo na gospodarske in negospodarske dejavnosti, ki pa jih po klasifikacijski teoriji uvrščamo v terciarni sektor. Še do nedavnega smo po naši klasifikaciji dejavnosti strogo ločili terciarni sektor, kamor smo uvrščali t. i. gospodarske storitvene dejavnosti (gradbeništvo, trgovina, infrastrukturna oskrba, gostinstvo, promet, finančno posredništvo, nepremičnine, obrt in osebne storitve) od kvartarnega sektorja oziroma negospodarskih storitvenih dejavnosti (javna uprava, obramba, socialno zavarovanje, izobraževanje, zdravstvo, socialno varstvo ter družbene organizacije in skupnosti). Mejo med terciarnimi in kvartarnimi dejavnostmi je težko potegniti tudi zaradi drugačnega tolmačenja pojma družbene dejavnosti, ki so bile $\mathrm{v}$ preteklosti ločene in tudi vnaprej načrtovane. $\mathrm{V}$ osnovi so to vendarle storitvene dejavnosti. Zaradi tega obravnavamo $\mathrm{v}$ kategoriji terciarnega sektorja vse dejavnosti, ki niso zajete $\mathrm{v}$ primarnem in sekundarnem sektorju dejavnosti.

Po uradnih podatkih Statističnega urada RS je bilo v letu 2005 v Sloveniji 813000 delovno aktivnih prebivalcev. Delež zaposlenih v terciarnem sektorju dejavnosti je predstavljal $70 \%$ (leta 1995 komaj $44 \%$ ). 
Po podatkih iz leta 2004 je bilo v Mestni občini Ljubljana evidentiranih 30180 poslovnih subjektov, od tega $90 \%$ s področja terciarnih dejavnosti. Od 163.600 zaposlenih, jih je samo $13 \% \mathrm{v}$ primarnem in sekundarnem sektorju dejavnosti. V primerjavi z letom $1995 \mathrm{se} \mathrm{v}$ Ljubljani ni bistveno spremenila struktura poslovnih subjektov, pač pa struktura zaposlenih, saj se je delež zaposlenih v terciarnem sektorju od takratnega 62-odstotnega deleža dvignil kar na $87 \%$. Največji delež (19\%) znotraj terciarnega sektorja zaposlenih predstavlja dejavnost G (trgovina, popravilo motornih vozil), s 17-odstotnim deležem sledi dejavnost L (javna uprava, obramba, socialno zavarovanje) ter dejavnost K (nepremičnine, najem in poslovne storitve) z deležem dobrih 15 \%. Visok delež zaposlenih v javni upravi kaže na dejstvo, da je MOL tudi glavno mesto Republike.

Slika 1: Struktura zaposlenih v terciarnih dejavnostih v Mestni občini Ljubljana

Figure 1: Structure of employment in the tertiary sector in the Municipality of Ljubljana.
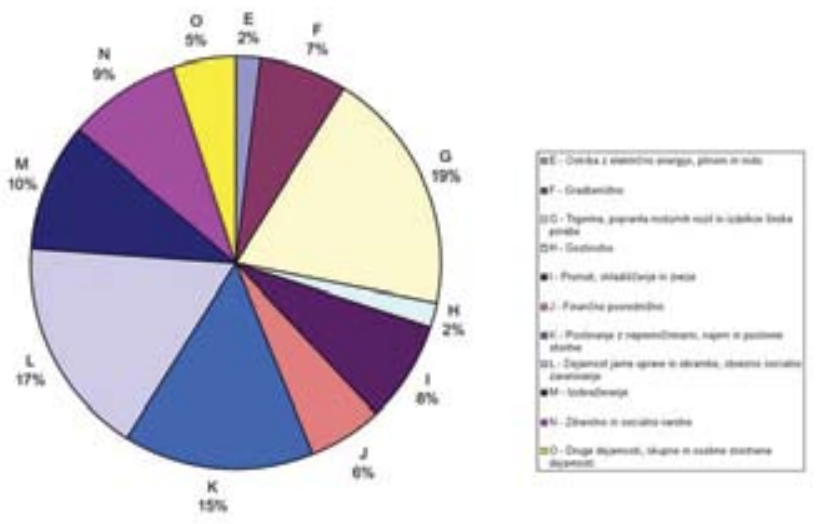

Kljub izredni rasti vedno bolj kvalitetnih storitvenih dejavnosti, pa se je njihova razporeditev znotraj mesta spremenila. Mestno središče je kljub atraktivnosti v nekakšni krizi. Najprej se je to pokazalo pri trgovini na drobno, ki ni več vzdržala konkurenčnosti in se je preselila na obrobje. S prenosom čedalje več asortimentov in trgovskih strok na obrobje se prodaja $v$ mestu iz leta $v$ leto zmanjšuje. Po letu 2000 se je trend selitev prenesel tudi na druge osebne in podjetniške storitvene dejavnosti. To situacijo je spretno izkoristil BTC, delno tudi drugi trgovski centri, kot npr. Rudnik, Vič in Šiška.

\section{Fenomen blagovno trgovskega centra $v$ Jaršah}

Na območju današnjega kompleksa BTC so prevladovala od leta 1954 do 1975 centralna javna skladišča, po tem letu pa se je preusmeril v blagovno transportni center, ki je leta 1987 postal že največji kopenski terminal v Evropi. Po letu 1990, ko je bila odprta prva trgovina, se je začelo območje spreminjati v blagovno-trgovinski center (BTC), ki beleži danes že preko 18 milijonov letnih obiskov. BTC, imenovan BTC City, postaja najpomembnejše slovensko 
poslovno, nakupovalno, rekreativno-zabaviščno in kulturno središče. Po površini je na tretjem mestu na svetu, za središči Alberta in Minnesotta, po številu obiskovalcev pa na 4.mestu. Do leta 2000 so prevladovala le skladišča in trgovine, po tem letu pa je izreden porast tudi ostalih storitvenih dejavnosti. Iz spodnjih dveh fotografskih posnetkov si komaj predstavljamo beg trgovin iz idiličnega mestnega sredičča $\mathrm{v}$ navidezno neprivlačno območje, kjer je skoncentriranih preko $360.000 \mathrm{~m}^{2}$ poslovnih površin. Največ površin (42\%) zaseda preko 430 trgovin. $Z$ vabljivim programom se v BTC selijo tudi druge storitve, zlasti informacijska in računalniška podjetja. V BTC-ju je našlo zaposlitev preko 4500 ljudi. Z zanimivim kulturnim in športnim programom mu je uspelo pritegniti potrošnike $\mathrm{z}$ različnimi potrebami in ustvariti novo kulturo druženja.

Slika 2. Število obiskovalcev po letih v BTC Cityju (BTC, 2006)

Figure 2. Number of visitors by year in BTC City (BTC, 2006).

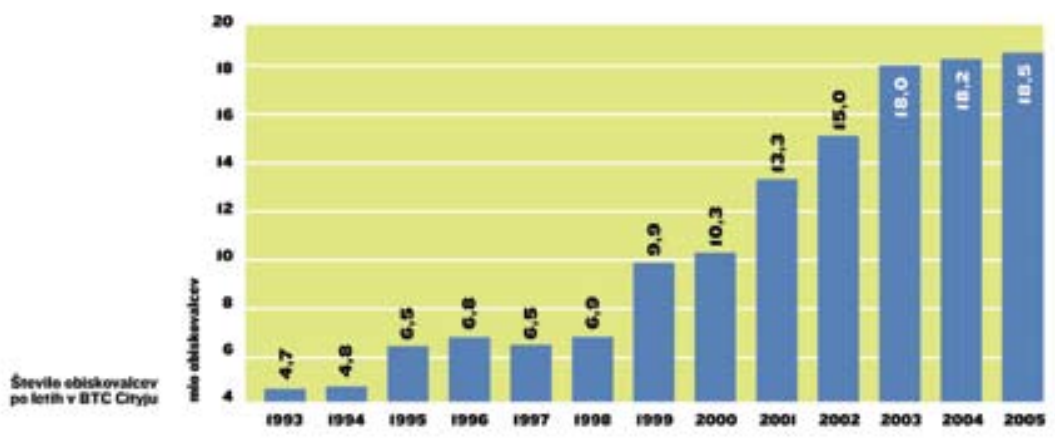

Slika 3. Razporeditev središč v BTC Cityju

Figure 3. Distribution of centres in BTC City.

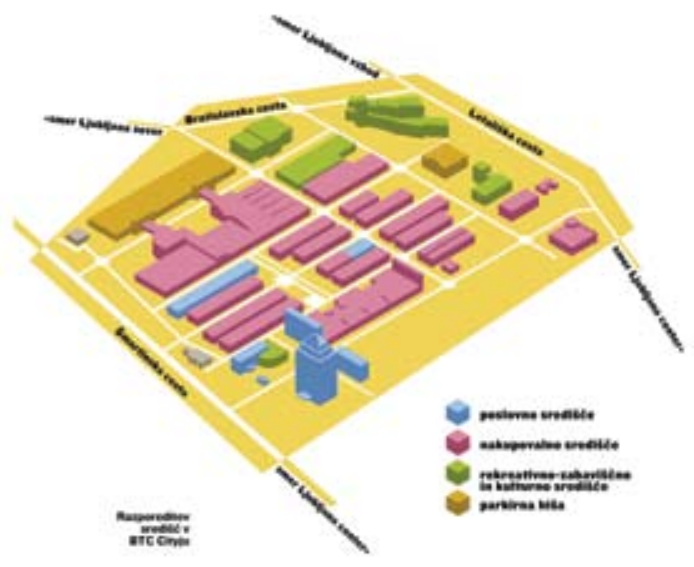


Odločitev je naša ...

The decision is ours ...
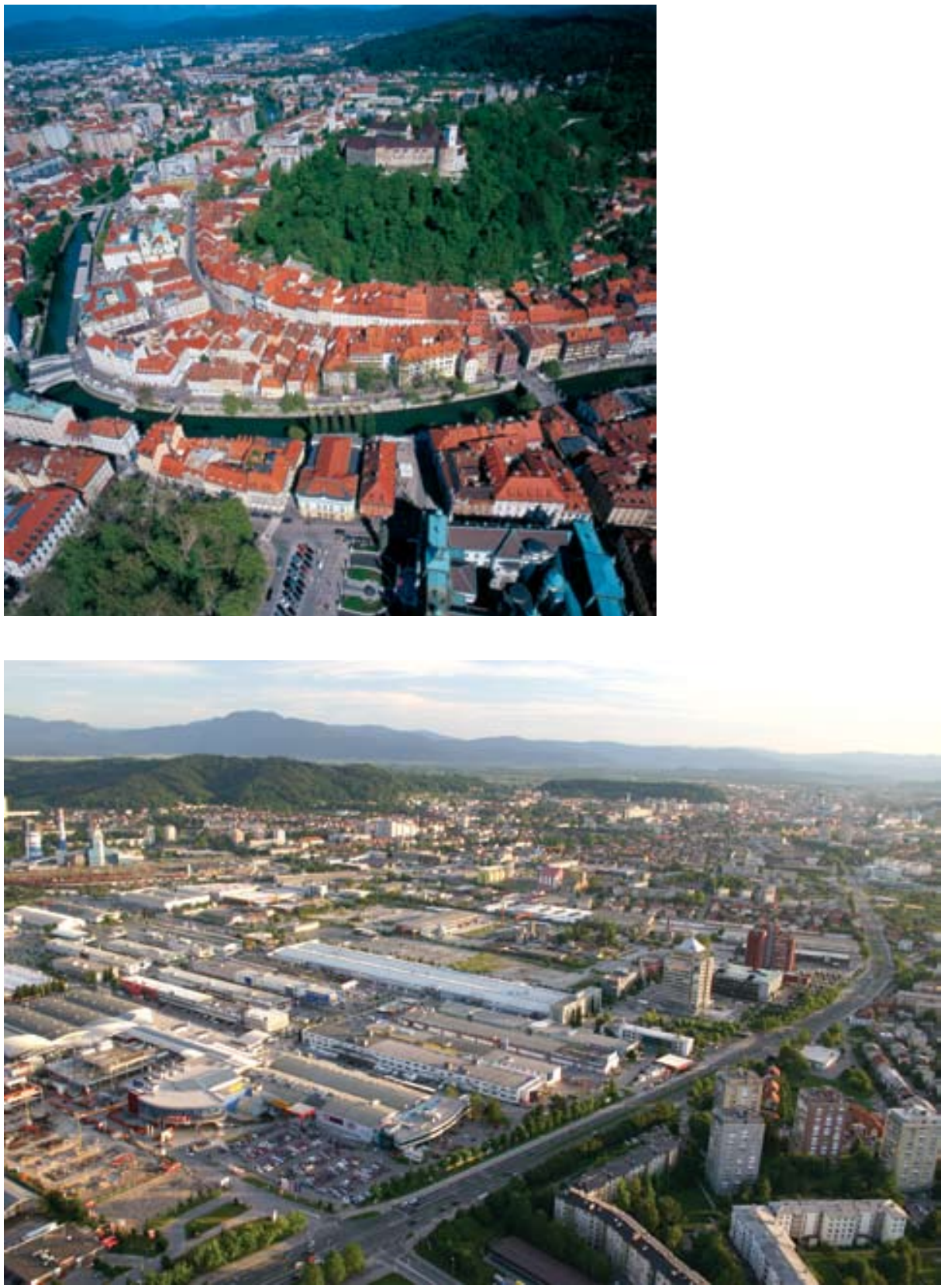

Vir: BTC, 2006 


\section{ZAKLJUČEK}

Na koncu lahko povzamemo, da pojmi storitve, njihova delitev na terciarni/storitveni in kvartarni sektor, zaenkrat še nimajo enotne in določene definicije. Poleg teoretske nedoločljivosti prihaja tudi do problema razvrščanja dejavnosti znotraj samega terciarnega sektorja. Nadaljnje nejasnosti nastopajo tudi pri načinu opazovanja (npr. ali je težišče gledanja dejavnost podjetja ali funkcionalno opazovanje posameznih dejavnosti). Ne glede na nadaljnjo razmejevanje, je po statističnih podatkih jasno, da terciarni sektor zelo hitro narašča, zlasti na področju enostavnih storitev. Terciarni sektor daje priložnost večjemu zaposlovanju žensk, ne samo na področju nižje kvalificiranih delovnih mest, pač pa tudi na visokokvalificiranih mestih. Potencialne možnosti so zlasti na medijskem, komunikacijskem in informacijskem področju. Povpraševanje po enostavnih storitvah bo ostalo, vendar se bodo sprožili večji premiki med formalnim delom in neformalnimi dejavnostmi, kakor tudi razmerja med zasebno in javno sfero.

$\mathrm{Z}$ vidika prostorskega načrtovanja, igrajo terciarizacija in specializacija storitvenih dejavnosti pri tekmovalnosti lokacije aglomeracij osrednjo vlogo. Planiranje in politika se trudi za svoje mesto najti niše specializacije, da bi vsaj kratkoročno izrabili prednosti zgostitvenih jeder, ki bi lahko imele tudi mednarodni zgled. V planski strategiji zaradi ohlapnih lokacijskih faktorjev ni enostavno predlagati ali vplivati na razvoj določene dejavnosti. Izbor je bolje, da se prepusti ciljno usmerjenemu marketingu mesta ali pa vplivom razvojne politike $\mathrm{z}$ vidika že znanih virov. Odločitev, kam naj gre v bodoče razvojna pot aglomeracij, bodo morali dati politiki in planerji mestnih središč in robnih aglomeracij skupaj.

\section{Viri in literatura}

Baethge, M.,1999. Empfehlungen des Expertenkreises »Dienstleistungsbeschaeftigung im 21. Jahrhundert, SOFI, Soziologisches Forschungsinstitut an der Universitaet Goettingen, Goettingen.

Blotelvogel, H.,2004. Handels-und Dienstleistungsgeographie, UNI-Dortmund, predavanja, Dortmund.

BTC City 2006, Mesto odlik in vedrine, Portret družbe BTC D.D..

Clark, C.,1940. The conditions of economic progress, London.

Fourastie J., 1954. Die grosse Hoffnung des zwanzigsten Jahrhunderts, Koeln.

Jaeger, W., 2002. Zukunft der Arbeit und Regionale Strukturentwicklung, Podiumsdiskussionsbeitrag zu den 2. Leverkusener Hochschultagen »Zukunft der Arbeit« vom 24. Septemeber 2002, (Veröffentlichung in Vorbereitung), Hagen. www.fernuni-hagen.de/ soz/soz4/texte/strukturentwicklung.pdf.

Neuhoff, A.,1998. Zum Standortsystem der hoeherrwertigen Unternehmensorientierten Dienstleistungen, UNI Duisburg, Duisburg.

Paal, M., 2005. Metropolen im Wettbewerb. Tertiärisierung und Dienstleistungsspezialisierung in europäischen Agglomerationen. - Münster, Marburg.

Pak, M.,1967. Socialno geografska transformacija nekaterih mestnih četrti Ljubljane in Maribora, Geografski vestnik, 39/67, str. 123-142, Ljubljana. 
Pak, M., 1972. Nekateri osnovni procesi transformacije mestnega prostora in njegove strukture, Geografski obzornik, 3/72, Ljubljana.

Pak, M. ,1973. Oskrba kot dejavnik transformacije mestnega prostora na primeru Maribora, Geografski simpozij o Severovzhodni Sloveniji, GeographicaSlovenica, Ljubljana.

Pak, M., 1973. Trgovska središča v Ljubljani, Mariboru in Kranju: (Nekaj geografskih elementov v organizaciji oskrbe), Geografski vestnik, 45 /73, str. 47-70, Ljubljana.

Pak, M., 1990. Problematika terciarizacije mestnega jedra v Kopru, Primorje / [urednik Milan Orožen Adamič]: Zveza geografskih društev Slovenije, str. 177-182, Ljubljana.

Pak, M., Slavec A., 1994. Gospodarska problematika Maribora. V: Maribor-Marburg: Prispevki h geografiji prijateljskih mest v Sloveniji in Nemčiji, Pedagoška fakulteta Maribor, Maribor.

Pak, M.,2000. Ljubljana je socialno in funkcijsko vedno bolj heterogena, Delo, (18. okt. 2000), str. 32 (Znanost), Ljubljana.

Pak, M.,2000. Problematika funkcijske zgradbe Ljubljane, Program, povzetki / 18. zborovanje slovenskih geografov, Ljubljana 19. -21. oktober 2000. Ljubljansko

geografsko društvo, Ljubljana.

Pak, M., 2002. Funkcijska zgradba Ljubljane, Geografija Ljubljane / [urednik Mirko Pak. Ljubljana: Oddelek za geografijo Filozofske fakultete, Ljubljana.

Pak, M., 2004. Specifični elementi v funkcijski zgradbi Ljubljane, Dela, 22, Ljubljana.

Pak, M., Rus, A., 2005. Problematika razvoja mest in spreminjanje rabe prostora, Dela 24, str.159-170, Ljubljana.

Rebernik, D., 2003. Priložnosti in možnosti regionalnih strukturnih poti k združeni Evropi, Mednarodni medinštitutski geografski seminar, Ljubljana, 12.-13. april 2002. Ljubljana: Oddelek za geografijo, Filozofska fakulteta, Delo, str. 165-175, Ljubljana.

Rus, A., Stanič, I., 2000: Notranja členitev Ljubljane in njeno povezovanje z urbano regijo. Ljubljana - geografija mesta, str.267-276, Ljubljana.

Statistični letopis 2006, Statistični urad RS.

Statistični letopis Ljubljane 2005, Mestna občina Ljubljana, Center za informatiko, Služba za mestno statistiko in analize.

\section{THE SIGNIFICANCE OF THE SERVICE SECTOR FOR THE DEVELOPMENT OF LJUBLJANA}

\section{Summary}

During the last three decades we have been witness to a shift in economic transformation from material manufacturing activities (secondary sector) to immaterial ones in all major European urban centres, as well as those in Slovenia. We are witness to significant restructuring of employment, whereby traditional industrial disciplines are being substituted by new activities. Not only are these changes causing increased competitiveness in the entire urban system, but also competitiveness within the cities themselves, also implying competitiveness between the city centre and periphery. Cheaper and above all easily attainable land on the city edge, with good accessibility and available parking space have triggered a process of 
transferring service activities to the urban fringe, even those that were formerly seen as essential for the functioning and growth of city centres (e.g. finance and insurance).

The article presents an attempt at defining the term tertiary (service) activities that have been rapidly developed during the last sixty years. According to the traditional definition the tertiary (service) sector differs from the primary and secondary sectors because it doesn't place in the forefront production of material goods but above all offers immaterial service. Development has shown that the sector is also growing on account of entrepreneurial services, yet is becoming increasingly dependent on technological development (information and telecommunication technologies). Alongside simple distinctions between services there have also occurred massive changes in the field of "high added value" service activities, which can be explained in various ways. The heterogeneity of service activities includes terms, such as: production services, information sectors, fourth sector, intellectual services, business services etc. This means all activities that demand a better educated workforce and access to company decision-making processes. Development of tertiary activities doesn't suffice on dispersal of activities, but on the contrary, demands specialisation and linkages between similar disciplines (e.g. financial services), also meaning implicit concentration of experts. Similarly, concentration of particular service activities isn't necessarily locally based, since demand and exchange of information can have a much broader basis. For example financial and insurance services are also tightly linked to marketing. Specialisation of services can inherently carry new development impulses, which can lead to takeovers on the national and international level.

Official census data of the Statistical Office of the Republic of Slovenia show that in 2005 Slovenia had an active workforce of 813.000 people. The share employed in service activities was 70 percent (compared to barely 44 percent in 1995). In 2004 there were 30.180 registered businesses in the Municipality of Ljubljana, of which 90 percent were engaged in service activities. Of the 163.600 employed only 13 percent were employed in the primary and secondary sectors. Compared to 1995 the structure of businesses didn't change significantly, but the structure of employees did. The share of employees in the tertiary sector grew from 62 percent to 87 percent. The largest share of employees in the tertiary sector (19 percent) are in activities termed " $G$ " (retail, repair of motor vehicles), followed by 17 percent in activities "L" (public administration, defence, social insurance) and activities "K" (property market, renting and business services) with almost 15 percent. The high share of employees in public administration points to the fact that Ljubljana is also the capital city of Slovenia.

Despite the exceptional growth of increasingly better service activities, their distribution in the city has changed. The city centre, despite its attractiveness is in a specific crisis. The first indicator was with small scale retail, which couldn't counter the competition of out of town shopping centres. The ongoing transfer of various assortments and retailing branches can also be seen from the decreasing share of retail in the city. After 2000 the trend shifted to other personal and business services as well, which were picked up by BTC and also other out-oftown centres, such as Vič, Rudnik, Šiška.

The phenomenon of the goods and retail centre in Jarše.

Between 1954 and 1975 the area occupied by the present BTC complex was used for warehousing. Then they shifted to transport and logistics and by 1987 were the largest 
continental terminal in Europe. After 1990, when the first shop opened its door to shoppers, the area started transforming into a retail and leisure centre coined BTC City. Today they have more than 18 million visitors annually. BTC City is becoming the country's most important business, shopping, leisure and entertainment and cultural centre. Its area makes it the third largest centre in the world (closely behind Alberta and Minnesotta), while its volume of visitors puts it in 4th place. Until 2000 warehouses and shops were prevalent, since then other services have also seen exceptional growth. From the two photographs one can hardly imagine the flight of shops from the idyllic city centre to this apparently unattractive area, where there is a concentration of more than $360.000 \mathrm{~m}^{2}$ of office and retail space. The majority is taken by the 430 shops (42 percent). Tempting conditions are also attracting other services, especially IT companies. BTC offers more than 4500 jobs. Its interesting cultural and sports programmes have also attracted consumers with different needs, thus creating a new culture of socialising.

From the aspect of physical planning, tertiarisation and specialisation of service activities play a significant role in the competitiveness of agglomerations. Planning and politics are trying to find for their cities specialisation niches that could, in the short run, utilise the advantages of concentration cores and have international effects. Because of lax location factors planning strategies have difficulties in providing sites and affecting development of certain activities. Probably it is better to relinquish this activity to goal-driven city marketing or the influences of known development policies. Decisions concerning the development course of agglomerations will have to be taken jointly by politicians and planners of city centres and edge-city agglomerations. 